\title{
Action groups as a participative strategy for leading whole-school health promotion: results on implementation from the INCLUSIVE trial in English secondary schools
}

Warren, Emily ${ }^{\mathrm{a}}$; Bevilacqua Leonardo ; Opondo, Charles $^{\mathrm{c}}$; Allen, Elizabeth ${ }^{\mathrm{c}}$; Mathiot, Anne ${ }^{\mathrm{b}}$; West, Grace ${ }^{\mathrm{b}}$; Jamal, Farah ${ }^{\mathrm{d}}$; Viner, Russell ${ }^{\mathrm{b}}$; Bonell, Chris ${ }^{\mathrm{a}}$.

a-London School of Hygiene \& Tropical Medicine, 15-17 Tavistock Place, London, WC1H 9SH, UK

b-UCL Great Ormond St. Institute of Child Health, 30 Guilford St, London WC1N 1EH, UK c- London School of Hygiene and Tropical Medicine, Keppel Street, London WC1E 7HT, UK

d- UCL Institute of Education, Bedford Way, London WC1H 0AL

Corresponding author: Chris Bonell

Physical address: London School of Hygiene \& Tropical Medicine, 15-17 Tavistock Place, London, WC1H 9SH, UK

Email address: chris.bonell@1shtm.ac.uk

Telephone: 02076127918

Word count: 5,990

Figures: 1

Tables: 3

\section{Acknowledgements}

This paper presents independent research funded by the National Institute for Health Research (NIHR) in England under its Public Health Research programme (12/153/60) and the Education Endowment Foundation. The views expressed in this publication are those of the authors and do not necessarily reflect those of the National Health Service (NHS), the NIHR or the Department of Health for England.

Miranda Perry played a key role in developing the intervention and coordinated its implementation in the pilot and phase III trials.

We are grateful to the staff and students of participating schools for their dedication to the intervention and completion of the outcome surveys and process evaluation surveys and interviews. We are very grateful for the advice and support of our Trial Steering Committee and Data Monitoring Committee. 


\section{Action groups as a participative strategy for leading whole-school health promotion: results on implementation from the INCLUSIVE trial in English secondary schools}

\section{Abstract}

Education policy increasingly promotes action groups as a key strategy for student and/or staff participation in school improvement and whole-school health promotion. Such groups can coordinate multi-component interventions, increase participation and engagement, and enable local adaptations, but few process evaluations have assessed this. We evaluated fidelity, feasibility and acceptability of action groups as part of a trial of a whole-school intervention to reduce bullying and aggression and promote health in English secondary schools, which reported multiple health and educational impacts. Action groups involved students and staff, supported by external facilitators and drew on data on student needs. They aimed to: coordinate implementation of restorative practices and a social and emotional competencies curriculum; review policies and rules; and enact local decisions to modify school environments. Our process evaluation used interviews, focus groups, observations and questionnaires to assess action groups': fidelity; role in coordination; role in local adaptation; support from external facilitators and data on student needs; and acceptability in engaging members. Fidelity was high in the first two years but lower in the third year when external facilitators withdrew. Student needs data were perceived as useful but views on external facilitators were mixed. Groups successfully reviewed policies and rules, planned activities, and coordinated restorative practices, but were less successful in implementing the curriculum. Success was facilitated by involvement of school leaders. Members reported high satisfaction and empowerment. Action groups are a promising strategy for leading whole- 
school health promotion. Implementation is supported by external facilitation, local data and involvement of senior managers.

250 words

\section{Key words}

Action groups; whole-school interventions; fidelity; implementation 


\section{Action groups as a participative strategy for leading whole-school health promotion: results on implementation from the INCLUSIVE trial in English secondary schools}

\section{Introduction}

Action groups (AGs) are decision-making bodies that involve school staff and/or students. They are one approach to promoting 'student voices' in which students have a say in the running of schools, and are increasingly used to implement whole-school interventions to aid school improvement and promote student health (Department for Education, 2014). AGs provide a practical means of promoting a systems-based, ecological approach to render school environments more health-promoting. They have been theorised, for example, to enable positive 'disruptions' to school systems which can lead to improved staff-student relationships and school systems being more attentive to student needs and concerns, which in turn may increase student engagement with school and decrease involvement in risk behaviours (CP Bonell et al., 2013; Bronfenbrenner, 1979; Markham \& Aveyard, 2003).

There is evidence from a number of trials that AGs are an important element in school-based health interventions. Our own 'INCLUSIVE' randomised controlled trial (RCT) reported that 'Learning Together', a whole-school intervention comprising AGs as well as restorative practice and a student social and emotional competencies curriculum (figure 1: logic model), was effective in preventing bullying victimisation, as well as preventing smoking, use of alcohol and drugs and contact with police, and promoting mental wellbeing, psychological functioning and health-related quality of life [reference anonymised]. The present paper reports from the process evaluation of this trial. 
Previous trials have also reported positive results on whole-school interventions involving AGs. The Gatehouse intervention included organisation-change and classroom-curriculum components to promote the emotional and behavioural wellbeing of young people in Australian secondary schools. In each school, an 'adolescent health team' comprising staff, community representatives and an external facilitator, drew on information from student surveys to identify risk and protective factors for each school and locally appropriate strategies to address these. An RCT reported mixed effects, including no effects on depressive symptoms but significant benefits for smoking, alcohol use and a composite measure of risk behaviour (Bond et al., 2004; Patton et al., 2006). A similar intervention, implemented in middle schools in Chicago, involved a local school task force, including staff, students, parents and community members, which oversaw implementation, modified school policies and developed school-community collaborations. A central aim of the task force was to transform the school community to promote a sense of belonging among all members of the school community. An RCT reported that for boys, the intervention was associated with reductions in violent behaviour, drug use and recent sexual intercourse (Flay, Graumlich, Segawa, Burns, \& Holliday, 2004).

The Safer Choices intervention aimed to prevent sexually transmitted infections and pregnancies among US adolescent via a multi-component intervention comprising a curriculum, student-led advocacy and parent information. Intervention activities were coordinated by a school health promotion council comprising teachers and administrators, students, parents and community representatives. An RCT reported a range of impacts reducing sexual risk behaviours (Basen-Engquist et al., 2009; Coyle et al., 2001; Coyle et al., 1999). The PREPARE intervention was a multi-component, school-based prevention intervention to promote sexual health and decrease intimate partner violence (IPV) among 
young adolescents in South Africa. A team was convened in each school comprising the principal, teachers, the school safety officer, parents and local police. The teams undertook a safety audit to inform a local safety plan aiming to reduce the acceptability and prevalence of IPV and sexual violence. An RCT reported reduced rates of IPV in intervention schools (Mathews et al., 2016).

The questions examined in this paper concern the role that AGs play and how they are implemented. AGs are potentially important for three reasons. First, they enable coordination of whole-school interventions that are frequently complex and multi-component. Such interventions are feasible to implement in schools and are effective in promoting health across a range of outcomes (Langford et al., 2014), with greater impacts than for singlecomponent interventions such as health-education lessons (Greaves, Sheppard, \& Abraham, 2011). Coordination through an AG is likely to be important to ensure components interact synergistically (Craig et al., 2008).

Second, AGs can enable local adaptation. There is a debate in the literature about whether implementation of health promotion should prioritise fidelity to maintain 'active ingredients' (Mihalic, 2004) or prioritise adaptation to operationalise an intervention's theory of change in a locally appropriate manner (Dane \& Schneider, 1998; Hawe, Shiell, \& Riley, 2004). The appropriate balance will likely vary between intervention types; whole-school interventions aiming to modify school environments may require more adaptation because they function as ‘interruptions to complex systems', building on existing capacity (Hawe et al., 2004; Quinn \& Kim, 2017). However, adaptation should be planned and ensure fidelity to the theory of change (Hawe et al., 2004), suggesting a role for AGs using standardised processes for adaptation. 
Third, AGs can promote staff and student participation in decisions, ensuring interventions attend to stakeholder preferences and potentially generating health benefits because such participation can promote student commitment to school (Hulpia, Devos, \& Rosseel, 2009), which is associated with reductions in health risk behaviours (C. Bonell et al., 2013).

While it is clear that AGs have been central to a number of effective whole-school health interventions, only the Gatehouse project included a process evaluation. This reported that although teams could take time to assemble and organise themselves, they were crucial in implementing whole-school change particularly in coordinating the work of disparate decision-makers across the school to build consistent policies and systems on existing work (Bond, Glover, Godfrey, Butler, \& Patton, 2001). The team-based approach empowered members to voice their opinions, initiate and implement change, and increase the profile of health and wellbeing across the school. The use of information from student surveys in the Gatehouse project was an important element of the action teams' work, providing an impetus for action, securing the interest of senior staff and informing priorities. The external facilitators deployed to help implement action teams were viewed as important in maintaining momentum and linking schools with external sources of support (Glover \& Butler, 2004). Facilitators reported that they sometimes needed to reframe public health issues, such as mental health, into more educational concepts such as school engagement, and align them with schools' institutional priorities. Facilitators reported that the intervention worked best where teams included diverse staff who shared ownership. However, the Gatehouse process evaluation did not report on the fidelity of delivery of action teams or the extent to which the teams adapted the intervention. 
We will build on these findings to examine the following research questions: with what fidelity were AGs implemented?; what role did AGs play in coordinating the intervention?; to what extent were AGs supported by the provision of external facilitators and data on student needs?; what approach did AGs take to local adaptation?; and were AGs acceptable to, and engaging and empowering for their members?

\section{Methods}

\section{Trial methods}

Here we provide a summary of methods, which are described fully in the published protocol and main trial report [reference anonymized]. We undertook a two-arm repeat cross-sectional RCT ('INCLUSIVE') of the Learning Together intervention in 40 secondary schools across south-east England. Our study population consisted of all students in the school at the end of year 7 (11-12 years) at baseline in March-July 2014, and at 24-months (end of year 9; aged 13-14 years) and 36-months (end of year 10; aged 14-15 years) follow-up. Schools were randomly allocated after baseline surveys with a 1:1 ratio to intervention or control arm, stratified by: single-sex versus mixed-sex school; school-level student eligibility for free school meals as an indicator of family benefits entitlement $(0-23 \% ;>23 \%)$; and school-level performance in General Certificate of Secondary Education examinations accounting for student attainment on entry to the school as a measure of academic progress (above and below the median score for England of 1000). Schools randomised to the control group continued with their normal practice and received no additional input. 
Schools allocated to the intervention group were provided with resources to facilitate implementation of AGs, restorative practice, and a social and emotional competencies curriculum. AGs comprised at least six staff and six students (not parents), led by a member of the school's senior leadership team. Restorative practice is an approach to discipline aiming to improve relationships to prevent and/or resolve conflicts (Morrison, 2005) using 'circle-time', which brings staff and students together to maintain good relationships, 'conferencing', which brings together the relevant parties to a conflict to find ways to improve relationships to avoid further harms. All school staff received basic training to implement restorative practices and 5-10 staff per school received in-depth training to deliver restorative conferences. Schools were provided with lesson plans and slides to guide delivery of 5-10 hours per year of a classroom social and emotional competencies curriculum for students in the trial cohort moving through years 8-10 (age 12-15 years). To support AGs, schools were provided with: a manual; external facilitator in the first two but not the third year of intervention (when schools were expected to be self-facilitating); and a report summarising the findings from student surveys on attitudes to and experiences of school. AGs aimed to coordinate intervention delivery across the school, and to revise school rules/policies and enact local decisions informed by survey data to support restorative approaches to school discipline and make the school environment more engaging and healthy. The intervention was universal primary prevention, and AGs were focused on intervention coordination and broader changes to the overall school environment. AGs were not focused on: outreach; targeted support to students with particular needs; coordination with other family or health services; or wider school inspections.

The intervention's theory of change was informed by the theory of human functioning and school organisation (Markham \& Aveyard, 2003) and postulated that the intervention would 
enable schools to reduce bullying and aggression, improve mental health and reduce substance use by increasing student commitment to school via improving relationships between staff and students and between academic education and students' broader development.

Primary outcomes for the trial were bullying victimization measured by the Gatehouse Bullying Scale (Bond et al., 2004) and perpetration of aggression measured by the Edinburgh Study of Youth Transitions and Crime Scale (Smith, 2006). Secondary outcome included smoking and use of alcohol and drugs, mental wellbeing, psychological functioning and quality of life and contacts with the police and NHS, which are described in our published protocol and main trial paper [reference anonymized]. The trial was prospectively registered as ISRCTN10751359 with the ISRCTN Registry on 30/01/2014. All amendments were approved by the independent study steering committee prior to collection of the 36-month surveys and any trial analyses.

\section{Process evaluation of $A G s$}

The process evaluation examined intervention implementation and receipt, guided by the trial protocol. The following aspects of the process evaluation occurred in every intervention school. External facilitators collected minutes and completed a diary for each meeting attended, which assessed: duration; attendees and their roles, gender and participation; use of survey data; priorities and actions set; revisions to rules and policies; and group dynamics. Researchers aimed to conduct structured observations of group meetings in ten randomly selected schools each year of intervention. Observation guides focused on the same areas as diaries. An anonymous survey was distributed to all members of AGs by facilitators at the end of each year 
of intervention. This explored: the diversity of staff and students on the AG; how well-led the group was; and how empowered members felt, using an adapted version of an existing scale (Frymier, Shulman, \& Houser, 1996). Participants placed the questionnaires in an envelope, which was sent to the researchers. Semi-structured telephone interviews with external facilitators ( $\mathrm{n}=6$ ) were conducted in years 1 and 2, lasting 45-90 minutes and exploring: school culture and priorities; interventions and adaptations and deviations; and barriers and facilitators to delivery. We aimed to interview two members (staff and student) of each school's AG per year. A member of the evaluation team contacted the AG leader and asked them to identify two individuals (staff and student) to interview. Interviews were semi-structured, lasted between 30-60 minutes, and explored views on: the acceptability of facilitators and the intervention; barriers/facilitators of AG meetings and how they might be improved; the extent to which actions arising from meetings were implemented in the school; and their impact.

Fidelity in the first two years was scored out of eight points for each school assessing whether: (i) at least five staff attended in-depth training (training records); (ii) six actiongroup meetings occured per year; (iii) policies and rules were reviewed; (iv) locally-decided actions were implemented (minutes); members reported that AGs had a good/very good range of members, and that groups were well/very well led (member survey); schools delivered at least five hours and/or two modules each year (curriculum survey); at least $85 \%$ of staff reported that if there was trouble at the school, staff responded by talking to those involved to help them get on better (staff survey). Fidelity in the third year was assessed using a narrower range of data since the research team access to schools was reduced. Out of four, schools were scored on whether: six AGs were convened; local decisions were implemented; schools delivered at least five hours and/or at least two modules; and at least $85 \%$ of staff reported 
that if there was trouble at the school, staff responded by talking to those involved to help them get on better.

Some aspects of the process evaluation occurred only in six case-study schools. These were purposively sampled in terms of diversity on: percentage of free school meals; facilitator; and the extent to which the school was responsive to intervention activities, as rated by the intervention facilitators three months into the intervention. In each year of intervention, we aimed to conduct one focus group with staff in each case study schools, each involving 4-6 members of staff. Staff were purposively selected and invited to participate by the staff member liaising with the research team to include diversity according to degree of participation in the intervention and role within the school (including senior leaders, pastoral staff and classroom teachers). Each year, we conducted focus groups with students in each case study school, comprising 4-12 students directly involved in intervention activities (including AGs). Focus group discussions aimed to explore school culture and ethos, views about the delivery and impacts of the intervention. Focus groups were conducted in private offices on school premises facilitated by one researcher. All interviews and focus groups were audio-recorded and transcribed.

\section{$\underline{\text { Analyses }}$}

Quantitative data were entered into CSPro or Excel and then transferred and analysed in Stata. Quantitative analysis used descriptive statistics to assess intervention fidelity, satisfaction and empowerment. Qualitative data were managed in NVivo and analysed to explore views about intervention processes and contexts. Analysis of qualitative data was undertaken by EW and $\mathrm{CB}$ who created an initial coding framework based on the research questions and theory 
guiding the intervention, with these codes augmented, refined and sub-categorised informed by an initial wave of coding inductively from the data. This employed invivo codes to identify recurring themes expressed in the data. A further wave of axial coding then explored interrelationships with these in vivo codes. Although primarily focused on recurrent themes in the data, coding employed some methods popularized in grounded theory approaches, such as constant comparisons and examination of deviant cases to refine the emerging analysis (Green \& Thorogood, 2004). The aim of the analyses was to establish a hierarchical set of themes which informed the structure of the narrative presented below. We used an adapted version of the Learner Empowerment Scale (LES) to assess the extent to which staff and student members felt empowered on the AG (Frymier et al., 1996). We report the mean percentage of positive responses across all items.

\section{$\underline{\text { Ethics }}$}

The trial was approved by the UCL research ethics committee (ref 5248/001). Written, informed consent was obtained from head-teachers for random allocation and for intervention, and from participating individuals for data collection. Participants received written information about their rights, consent, confidentiality, safeguarding and data management, and verbal information on the day of the research. Participants were informed that, were they to disclose that they or others had been involved in or were at risk of sexual or physical abuse, the research team would liaise with the safeguarding lead for the school, breaking confidentiality. No such reports were made. Participants were then asked to indicate their consent and reminded that they could cease involvement in the research at any time. Parents of students participating in data collection also received prior information and could withdraw their children from research if they wished. All data collected were stored on 
password-protected drives with access limited to those in the research team analysing the data.

\section{Results}

\section{$\underline{\text { Response rates }}$}

Most elements of the process evaluation achieved good response rates (table 1) but some, such as the survey of AG members in year 3, had lower response rates, reflecting that in this year not all schools delivered all aspects of the intervention.

\section{Intervention fidelity}

AGs were delivered with good fidelity in the first two years but lower in the third. In the first year, 19 schools completed all six AG meetings as intended but one convened only four meetings. In the second year, 11 schools completed six meetings, four held five, three schools held four, and one held three. Eleven schools achieved the target of holding at least six meetings per year in both years 1 and 2. Of these schools, only two maintained this level of meetings into the third year of intervention. In year 3, four schools did not hold any meetings.

Needs assessment surveys were completed in all schools with good response rates. Responses fell below $70 \%$ in only four schools, in year 3 only. According to facilitator diaries and meeting minutes, all schools in year 1 and 14 in year 2 reported using the needs data to inform priorities and actions. In year 3, four schools reported using the needs report to inform 
decisions. AGs at 17 schools succeeded in reviewing school policies and rules during years 1 or 2 .

All schools enabled their staff to receive introductory training in restorative practice and all but five schools sent at least five staff on the in-depth training. In all but eight schools, staff reported that restorative practice was extensively used. The curriculum was less well delivered with nine schools delivering the minimum content in the first two years and only five doing so in the third year.

\section{$\underline{\text { Coordinating action }}$}

As the data above indicate, most AGs successfully ensured that their school staff were trained in and delivered restorative practice but they were less successful in ensuring delivery of the curriculum. Most AG members in the majority of schools agreed that the group made good decisions (table 2). Members were less likely to agree that the group made sure these decisions were implemented, and this varied between schools.

This was also a common theme in interviews with facilitators and staff. According to its facilitator, one school's group revisited minor issues but was largely unable to confront bigger issues relating to student behavior, health or well-being. In another school, the AG proposed numerous actions that were rejected by the head-teacher.

The amount of work already facing teachers, within the pressurised culture of the English education system, made implementation more difficult. According to one facilitator, the teacher leading the AG in one school had: 
been given so much to do I think in his day-to-day role, it's just another thing for him to do.(Facilitator, school BE, interview, year2).

There was a clear trend that schools were better able to implement actions when members of schools' senior management sat on the AG or otherwise supported it. Head-teachers rarely sat on action groups, but in many schools deputy head-teachers led the groups and their presence enabled decisions to be implemented because these individuals possessed the authority to institute change. In other schools, the chair received little support from from the head or other school leaders.

The head teacher there was completely uninterested when I came to give a talk to the senior leadership team, and it's the only school where the head has not said anything to me or taken any notice or made any effort to be slightly friendly. It was awful. (Facilitator, school AH, interview, year 2).

In another school, despite there being no senior leaders on the group, the lead had worked for a long time at the school and was well respected and liked by both students and staff. Thus, it was possible to galvanise action without the formal involvement of senior leaders in some cases.

\section{$\underline{\text { Using local information }}$}

Our survey of AG members found that most individuals across most schools rated the needs assessment report as useful in informing decisions (table 2). Interviews with students and 
staff on AGs, as well as with facilitators, found that most valued the needs reports and used them to identify priorities.

They've been drawing on the needs assessment report [...]It's feeding into everything they do. So they...we focused on it quite a lot in meetings, pored over the data in the first few meetings. And then we still keep coming back to it when we're thinking about what next, what actions should we be doing? (Facilitator, school BM, interview, year 1)

\section{Use of data on student progress is normal within English schools, and staff were used to} employing data in decisions. Staff commonly suggested that they used the reports as evidence to advocate to school senior leadership teams for changes. In one school, for example, the needs report was useful to advocate on behalf of students whose concerns, though previously voiced, had not been acted upon. This was also the case in another school:

It certainly gave me some ammunition that I can say, 'Well this is...this is proven because the kids have actually said this, so we need to move forward with it'. (Assistant head-teacher, school AF, interview, year 2)

In a few schools, staff expressed shock or surprise at the results, particularly about the data on students feeling unsafe at school or uncomfortable talking to staff about problems. The reports often highlighted student concerns that staff had previously never considered, particularly relating to feelings of safety at school. Another school received a report that presented evidence of considerable student unmet needs and this information was accepted by school leaders: 
Well the positive thing is, the only way is up. The year group is a challenging year group. And I remember when [facilitator] came to present to [senior leadership team] and said how terrible our data was...it was like a tumbleweed moment; it was so funny. I mean...it wasn't funny in a good way, but...but it was a realistic...realisation for everyone if you know what I mean....Because we all knew it was like that, but we didn't realise how much the children didn't actually like us. (Member of pastoral team, school AM, interview, year 1)

Staff at two schools felt the report was not useful or valid. In particular, they felt the questions used vocabulary that was too advanced for many students with special educational needs or those with English as an additional language. They reported that the phrasing, particularly when students were asked to respond to negative statements, was inaccessible and that many of the questions were leading. In one school, the assistant head reported that when the school conducted its own surveys, their findings diverged from the intervention's needs report:

The data from the [AG report] is meaningless; completely meaningless.... It's the worst...it's a pointless exercise for our students. (Assistant head-teacher, school AE, interview, year 3)

Staff in three schools did not share some or all of the findings with students because it was seen as too long and complicated or inappropriate for students to see. Where year-on-year trends in such factors did not improve, staff-members sometimes reported feel dispirited. 
Such disappointments may have contributed to these school not continuing intervention activities in the final year of the study.

\section{External facilitation}

Most AG members rated the facilitator as useful for ensuring all members could have their say (table 2), helping groups make decisions, and ensuring that decisions were implemented, though this varied across schools. A key theme across interview data was many staff's mixed feelings about the facilitation. Some schools reported that the facilitator was relatively passive, listening and taking notes, while others felt that they simply did not contribute much or were generally dissatisfied with the facilitator's work:

They don't really do anything.... Whether they bring anything to the meeting. I think once or twice they might have asked a couple of questions, but that's about it. They sit there looking to us. (Role unknown, school AF, interview, year 1)

Other schools were not clear on what the role of the facilitator was meant to be and therefore had trouble setting reasonable expectations for what they should contribute to the group:

I think...[facilitator] has been really useful as a... So making sure we're doing what we're supposed to do in one respect is great. But then it's sometimes flipped into, well are we doing it right? And having [facilitator]'s presence there has always... are we being watched, judged or supported? (senior leadership team (SLT) member, school AW, Interview, year 2) 
Staff in other schools reported that the facilitator added gravitas to the meetings and reinforced the notion that they would be held accountable for progress:

So working with a facilitator from outside, that has been quite good at making it...just more...focused and more effective in that way. Because I think people in schools have really, really good ideas but again, because of the time, you tend to let things slip. Whereas this has kind of imposed a formality to it which means you have to keep to deadlines and move things forward. (Staff member, school AE, interview, year 1)

Most interviewees suggested that external facilitation was not necessary in the final year but a few suggested this was a significant loss:

The absence of [facilitator] has been incredibly significant because she ... was able to tie it in all the time to the agenda. And was a touchstone I suppose really for that. And then...so that...I think that was a loss. (SLT member, school AD, interview, year 3)

\section{$\underline{\text { Local decision-making and adaptation }}$}

AGs were effective as a means of making local decisions about planned adaptations to how the intervention was delivered in each school. This approach was well aligned with the autonomy over management decisions granted to schools in England. As recommended in the intervention manual, most schools used the survey data on local needs to decide local actions. Sixteen schools enacted local decisions in years 1 and 2. In year 3, ten schools completed locally decided actions. 
Common actions included: cascading training in restorative practice to staff who had not attended the in-depth, or to students so that they could work as peer mentors or buddies; delivering assemblies on restorative practice; staff patrolling hallways between classes to discourage aggressive behaviours; and instituting safe spaces on the school site. These actions appeared highly consistent with the intervention theory of change in their direct focus on student safety. Other actions appeared consistent with the theory of change in terms of aiming to increase student engagement in school. Some schools offered more after-school clubs. One offered drop-in services to improve engagement and various schools focused on girls' engagement. Also in line with the theory of change were actions to promote mental health. One school, for example, funded new, external specialist staff to work with students to improve mental health and wellbeing, including a counsellor and a boxing coach. Other actions were less obviously linked to the theory of change but might be construed as contributing to increasing engagement. Some schools made improvements to the physical environment, including decorating the schools with informational or motivational posters and displaying student work.

A few AGs deviated from the processes of working set out in the manual. Two schools broke the AG into multiple subcommittees. This was done in one school so that students were less intimidated speaking in front of a large group and, in the other school, so that multiple groups could get more done. Some schools used AG meetings for purposes other than to coordinate the intervention. A few schools used AGs to train students or staff in restorative practice or mentoring. One academically selective school did not view itself as having significant problems with bullying or aggression and therefore used the AG primarily as a way to revise the homework policy. 


\section{$\underline{\text { Participation }}$}

We drew on facilitator diaries and minutes to estimate the numbers of staff and students participating in groups. On average in year 1, 7.4 staff per school (range 3-12) participated in groups in schools for which data were available with this falling to 5.4 (range 2-9) staff per school in year 2. On average in year 1, 7.8 students per school (range 5-14) participated in AGs in schools for which we have data with this increasing to 8.8 (range 4-23) students per school in year 2. We did not calculate figures on participation in year 3 because schools implemented AGs in such heterogeneous ways. Schools were encouraged to, and most did, select a diversity of students to serve on the group including: by gender and ethnicity; those with a history of misbehavior; and those who struggled academically or who were at risk of disengagement. The schools involved served ethnically diverse populations and AG membership reflected this. A few focused recruitment on students who were high achievers or dropped lower attaining students from AGs. Most schools selected students across school years (age 11-16 years) to participate but some invited only those in the study cohort (i.e. age 12-13 years at the outset).

For the LES, the mean percentage of positive responses across all items among group members in intervention schools for which data were available was high (table 3). Over twothirds of members completing the survey reported that they worked hard on the group because they wanted to, not because they had to (table 2). Over $80 \%$ reported looking forward to meetings and almost $70 \%$ reported that meetings were exciting and energizing. Most members agreed that the group was a good way to ensure students contributed to decision-making with the results consistent across schools and years (table 2). 
In qualitative research, students said they valued the opportunity to express their views and highlight where they were unhappy, and AGs provided a calm, structured environment to do this:

I was able to speak from my own point of view, not just like statistics and what was on a piece of paper. Because I was able to like... I started...talking about my own experiences, the teachers were acknowledging it and... It kind of felt good because it's like...it's not me having to shout at a teacher or like I want to do this... It's difficult for a teacher with a class of thirty or more students. (Male, year-9 student, school BE, interview, year 2)

Students often reported that they felt that teachers on the group listened to students' views respectfully even when they disagreed with them:

That was good because we didn't feel intimidated by the teachers. Not that you felt intimidated before, but you didn't feel like... you could say something, all the teachers would listen... everyone put across their own views with no arguments or anything. (Student of unknown sex and year, school BE, focus group, year 2)

Students' confidence grew as a result of their involvement on the group:

Well at the beginning I was very conscious of not... sounding like an idiot, making a mistake, stuttering, something stupid like that. Now... it's completely different. I will...sometimes I will interrupt people. Obviously it's not a good thing but it just 
shows how I feel I can say what I want in this room. (Student of unknown sex and year, school BM, focus group, year 1)

But a theme across some staff accounts was staff's struggle to create positive interactions with students. Facilitator and interviews suggested that while many students participated meaningfully, others remained disengaged or, at times, combative:

They went down the road of all choosing students who were all, I would say, challenging. And therefore not necessarily always making an appropriate contribution to the group. I mean when I think back on it, out of the six students two of them contributed really well, and the other four were really a challenge. (Facilitator, school BD, interview, year 2)

Interviews and focus groups suggested that while student views were described as being taken seriously or very seriously in many schools, in other schools, staff only took note of student views when these were deemed 'realistic'. During the interview with a staff member at one school, these tensions became apparent:

They [students] want some rules to change; so they want to be able to bring their mobiles... There were a lot of conversations about, 'no....that's not [going to happen]...' And I think that they think they had a bigger input than they perhaps did. (Assistant head-teacher, school AH, interview, year 2) 
But other schools were enthusiastic about student participation in decisions. In one school, staff on the group expanded the process of revising school rules so that this involved students beyond the AG alone:

It came about through the Learning Together project. Very nice indeed, because the way it works...so the needs analysis said 'we don't know what the rules are'. [....] She got all the forms in form times with their form tutors to come up with rules about living in a community. How should we treat each other at [school AU]? And each form came up with you know lots of suggestions... I then took it to the staff and they had their say, and there were a lot of common themes, and we picked out all the favourites. I then took it leadership and we narrowed it down even more. (Assistant head-teacher, school AU, interview, year 2)

A recurring theme concerned the impact of the work on mutual understanding between staff and students:

It's also nice to be able to have a conversation with a teacher, because very often they're just the people at the front of the class... And they're just giving you the work; but when you actually have a conversation and you get to know them, you understand that they're real people and they're a lot more relatable. (Female year-10 student, school AU, interview, year 2)

This could lead to better relationships between staff and students: 
I think that's really good for me to be in something that's quite positive, because I do deal with quite a lot of negative in my role. So for the students to actually see me in a positive light within things like this I think is good for my role. Because then they'll stop and talk to me in the corridor: "Miss, are you going to the meeting tonight? Yeah, yeah, are you going?" So it's nice just to have that. And other people see them talking to me and go "Oh OK, she's not telling everyone off or talking about problems." (Role unknown, school BM, focus group, year 1)

\section{Discussion}

\section{Summary of key findings}

Regarding our first question about the fidelity of implementation, AGs were implemented well when an external facilitator supported them in the first two years of intervention but fidelity was reduced in the final year when this was withdrawn. However, some schools carried out the functions of the AG in the third year through pre-existing structures, such as student councils, representing a 'mainstreaming' of AG functions. Regarding the second question about the role of AGs in intervention coordination, AGs were successful in ensuring staff were trained in, and implemented, restorative practice but were less able to ensure implementation of the social and emotional competencies curriculum. This may have reflected the absence of curriculum coordinators from the groups or a lack of school support for the curriculum element. Groups were commonly led by deputy head-teachers (whose authority ensured decisions could be rapidly implemented) rather than by head-teachers. 
Regarding the third question about the importance of external facilitation and data on student needs, schools were generally satisfied with external facilitators and recognised their importance in galvanising action but felt that their roles could have been better defined. Some schools felt that facilitation could have been conducted internally without hampering the intervention. Data on student needs were an important resource for many schools, building commitment for the need for action and informing priorities and local actions. Several schools initially found the results shocking and two rejected the information and saw it as not useful.

Regarding the fourth question about AGs' approach to intervention adaptation, AGs succeeded in deciding locally appropriate actions in each school based on needs data and guided by a clear theory of change. Regarding the fifth question about acceptability, AGs were regarded as appropriately diverse, well led and able to make good decisions but sometimes as less able to ensure implementation. This was particularly so where groups did not include or were not supported by senior leadership teams. The AGs appeared to be an effective way to engage and empower staff and students in decision-making. Although some staff expressed doubts about their success in working with students, most students reported that they felt their views were taken seriously, and that working collaboratively with staff had transformed their relationships with staff and their experiences of school. We found no evidence that the work of AGs was more challenging or less acceptable because of their focus on mental health and bullying rather than merely physical health.

\section{Limitations}


We undertook a broad, deep and longitudinal process evaluation of the Learning Together intervention, which enabled examination of the workings of AGs. Although generally high, some aspects of the research had lower response rates. Despite this, our multi-source approach meant that we were still able to assess what was happening in most schools, with the exception of a few schools in year 3 where it is reasonable to assume that few if any intervention activities were being implemented.

\section{Implications for research and policy}

In line with previous literature, our study suggests that AGs are a feasible and acceptable means of implementing whole-school health interventions in secondary schools, providing a mechanism for coordinating and adapting complex whole-school interventions (Bond et al., 2001; Langford et al., 2014) via a process that enables broad participation and 'student voices' that is not tokenistic (Department for Education, 2014). Even though the work of AGs was taken forward in some schools via existing structures, our results suggest that use of a novel group was important to catalysing action. The AGs ensured that local decisions and adaptations occurred through a defined process so that locally appropriate adaptation nonetheless maintained the integrity of the intervention's theory of change, offering a practical means of achieving something previously discussed as a concept in the literature (Hawe et al., 2004). Like the Gatehouse project, our findings suggest that AGs can be effective in empowering diverse members to contribute to decisions (Bond et al., 2001) although for some schools, the inclusion of students regarded as challenging was perceived to make the AGs harder to run. However, in most schools the fact that these groups had a clear focus, drew on rigorous evidence of student need and were managed in a business-like 
manner appeared to encourage students, including those regarded as challenging, to treat them seriously.

Our findings also suggest that AGs may be an effective enabler of 'disruption' to school systems, bringing about benefits both through formal channels (for example, changes in school policies and practices) and via more informal routes (for example, students and staff developing more empathetic perspectives on each other and thereby improving relationships) as suggested in previous literature (CP Bonell et al., 2013; Markham \& Aveyard, 2003). Our sense is that the AGs could encourage schools to implement more inclusive and restorative (rather than authoritarian) approaches (Morrison, 2005), but that this was most feasible in those schools which already had a critical mass of staff who were supportive of such approaches. The intervention on its own would be unlikely to challenge school cultures where these were more authoritarian.

Participating schools were representative of those invited for participation and included a good range in terms of attainment, deprivation and inspectorate ratings, suggesting that similar benefits might be achieve were the intervention to be implemented in other secondary schools in England and beyond. We found some evidence that cultural specificities of the English education system enabled (for example, via the managerial autonomy schools are granted, and via teachers' regular use of student data to inform decisions) but also constrained (for example, via staff time-pressures and work-loads) the success of AGs. Other contextual enablers and barriers might operate in other systems and cultures and this should be explored in international studies. 
This study focused on young people age 11-15 in secondary schools, and further research is required to explore whether AGs can be implemented in primary schools with younger students. It might be that some aspects of AG's work, such as the encouragement of staff and students to empathise with each other's perspective, are less feasible in primary schools because younger children will generally have less well developed perspective-taking capacity (Dumontheil, Apperly, \& Blakemore, 2010). While our trial found evidence that the intervention was more effective in reducing health-related risk behaviours among boys than girls [reference anonymised], our process evaluation found no evidence that membership of or participation during AGs were greater for boys. Future whole-school interventions involving AGs should aim to promote gender equity both in AGs and other intervention elements, and evaluations should assess impacts by gender.

To optimise AGs in future intervention studies, more thought should be put into defining the role of facilitators and supporting groups to interpret and use data on needs, given that both our study and the Gatehouse project found that external facilitation was likely to be important (Bond et al., 2001). It may be that schools could use mutual-aid models in which one school's AG was facilitated by a staff-member from another school in the same area, chain or network. Our evaluation also provides further evidence that implementation of school-based interventions is facilitated by a local 'product champion' preferably a deputy head or other senior manager with the authority to drive action and an existing culture sympathetic with the aims of the intervention (C. Bonell et al., 2013; Bonell et al., 2009; Johnson, Hays, Center, \& Daley, 2004). While our study concluded that the direct involvement of head-teachers was not required, it is important that AGs operate with support from and communication with the school leadership teams. 
Our evaluation examined AGs that focused on universal, primary prevention of bullying and other health-related risk behaviours by modifying the school environment. Our AGs did not aim to: link with broader internal or external school inspection or improvement programmes; target the most disadvantaged students; or promote outreach to the community, for example linking marginalised families linking with specialist support (Downes \& Cefai, 2019). There is a need for further empirical evaluations to assess whether interventions involving AGs are feasible and effective in address these broader issues. 


\section{References}

Basen-Engquist, K., Coyle, K., Parcel, G.S., Kirby, D., Banspach, S.W., Carvajal, S.C., \& Baumler, E. (2009). School wide effects of a multicomponent HIV, STD and pregnancy prevention program for high school students. Health Education and Behavior, 28(2).

Bond, L., Glover, S., Godfrey, C., Butler, H., \& Patton, G. (2001). Building capacity for system-level change in schools: lessons from the Gatehouse project. Health Education and Behavior, 28(3), 368-383.

Bond, L., Patton, G., Glover, S., Carlin, J. B., Butler, H., Thomas, L., \& Bowes, G. (2004). The Gatehouse Project: can a multilevel school intervention affect emotional wellbeing and health risk behaviours? J Epidemiol Community Health, 58(12), 9971003. doi: 10.1136/jech.2003.009449

Bonell, C., Jamal, F., Harden, A., Wells, H., Parry, W., Fletcher, A., . . Campbell, R. (2013). Systematic review of the effects of schools and school environment interventions on health: evidence mapping and synthesis. Public Health Research, 1(1), 1-320.

Bonell, C., Sorhaindo, A., Strange, V., Wiggins, M., Allen, E., Fletcher, A., . . Rhodes, T. (2009). A pilot whole-school intervention to improve school ethos and reduce substance use. Health Education, 110(4), 252-272.

Bonell, CP, Fletcher, Adam, Jamal, Farah, Wells, Helene, Harden, A, Murphy, Simon, \& Thomas, J. (2013). Theories of how the school environment impacts on student health: Systematic review and synthesis. Health \& Place, 24, 242-249.

Bronfenbrenner, U. (1979). The ecology of human development: Experiments by nature and design. Cambridge, MA: Harvard University Press.

Coyle, K., Basen-Engquist, K., Kirby, D., Parcel, G., Banspach, S., Collins, J., . . . Harrist, R. (2001). Safer choices: reducing teen pregnancy, HIV, and STDs. Public Health Reports, 116(Suppl 1), 82-93.

Coyle, K., Basen-Engquist, K., Kirby, D., Parcel, G., Banspach, S., Harrist, R., . . . Weil, M. . (1999). Short-term impact of safer choices: a multicomponent, school-based HIV, other STD, and pregnancy prevention program. J Sch Health, 69(5), 181-188.

Craig, Peter, Dieppe, Paul, Macintyre, Sally, Michie, Susan, Nazareth, Irwin, \& Petticrew, Mark. (2008). Developing and evaluating complex interventions: the new Medical Research Council guidance. Bmj, 337, a1655.

Dane, U.A., \& Schneider, B.H. (1998). Program integrity in primary and early secondary prevention: are implementation effects out of control? Clinical Psycholog Review, 18( 1), 23-45.

Department for Education. (2014). Listening to and involving children and young people. London: Department for Education.

Downes, P., \& Cefai, C. (2019). Strategic clarity on different prevention levels of school bullying and violence: rethinking peer defenders and selected prevention. Journal of School Violence, Advance online publication http://dx.doi.org/10.1080/15388220.2019.1566915.

Dumontheil, I., Apperly, I.A., \& Blakemore, S.J. (2010). Online usage of theory of mind continues to develop in late adolescence. Developmental Science, 13, 331-338.

Flay, Brian R., Graumlich, Sally, Segawa, Eisuke, Burns, James L., \& Holliday, Michelle Y. (2004). Effects of 2 prevention programs on high-risk behaviors among African American youth: a randomized trial. Archives of Pediatrics \& Adolescent Medicine, 158(4), 377-384.

Frymier, A.B., Shulman, G.M., \& Houser, M. (1996). The development of a learner empowerment measure. Communication Education 45(3), 181-199. 
Glover, S., \& Butler, H. (2004). Facilitating health promotion within school communities. In R. Moodie \& A. Hulme (Eds.), Hands-on Health Promotion. Melbourne: IP Communications.

Greaves, C., Sheppard, K., \& Abraham, C. (2011). Systematic review of review of intervention components associated with increased effectiveness in dietary and physical activity interventions. BMC Public Health, 11, 119.

Green, J., \& Thorogood, N. (2004). Qualitative Methods for Health Research. London: Sage.

Hawe, P., Shiell, A., \& Riley, T. (2004). Complex interventions: how "out of control" can a randomised controlled trial be? British Med Journal, 328, 1561-1563.

Hulpia, H., Devos, G., \& Rosseel, Y. (2009). The relationship between the perception of distributed leadership in secondary schools and teachers' and teacher leaders' job satisfaction and organizational commitment. School Effectiveness and School Improvement, 20(3), 291.

Johnson, K., Hays, C., Center, H., \& Daley, C. (2004). Building capacity and sustainable prevention innovations: a sustainability planning model. Evaluation Program Planning, 27, 135-149.

Langford, R. , Bonell, C. P., Jones, H.E., Pouliou, T., Murphy, S. M., Waters, E., . . . Campbell, R. (2014). The WHO Health Promoting School framework for improving the health and well-being of students and staff. Cochrane Database of Systematic Reviews 2011, Issue 1. Art. No.: CD008958.

Markham, Wolfgang A, \& Aveyard, Paul. (2003). A new theory of health promoting schools based on human functioning, school organisation and pedagogic practice. Social Science \& Medicine, 56(6), 1209-1220.

Mathews, C., Eggers, S.M., Townsend, T., Aarø, L.E., de Vries, P.J., Mason-Jones, A.J., . . . De Vries, H. (2016). Effects of PREPARE, a multi-component, school-based HIV and intimate partner violence (IPV) prevention programme on adolescent sexual risk behaviour and IPV: cluster randomised controlled trial. AIDS and Behavior, 20(9), 1821-1840.

Mihalic, S. (2004). The importance of implementation fidelity. Emotional and Behavioral Disorders in Youth, 4(4), 83-105.

Morrison, B. (2005). Restorative justice in schools. In E. Elliot \& R. M. Gordon (Eds.), New Directions in Restorative Justice: Issues, Practices, Evaluation. Cullompton, UK: Willan Publishing.

Patton, G., Bond, L., Carlin, J.B., Thomas, L., Butler, H., Glover, S., . . Bowes, G. (2006). Promoting social inclusion in schools: group-randomized trial of effects on student health risk behaviour and well-being. American Journal of Public Health, 96(9), 1582-1587.

Quinn, D.M., \& Kim, J.S. (2017). Scaffolding fidelity and adaptation in educational program implementation: experimental evidence from a literacy intervention. American Educational Research Journal, 54(6), 1187-1220.

Smith, D.J. (2006). School experience and delinquency at ages 13 to 16. Edinburgh: Centre for Law and Society, University of Edinburgh. 
Table 1: Response rates

\begin{tabular}{|l|l|l|l|l|l|l|}
\hline \multicolumn{3}{|c}{} & Year 1 & Year 2 & Year 3 & Total \\
\hline \multirow{4}{*}{$\begin{array}{c}\text { All } \\
\text { schools }\end{array}$} & \multirow{2}{*}{ Interviews } & Facilitators & $8 / 8$ & $8 / 8$ & N.A. & $16 / 16$ \\
\cline { 3 - 7 } & $\begin{array}{l}\text { Action group } \\
\text { members }\end{array}$ & $28 / 40$ & $41 / 40$ & $28 / 40$ & $97 / 120$ \\
\cline { 2 - 7 } & Observations & Action group & $10 / 10$ & $9 / 10$ & $7 / 10$ & $26 / 30$ \\
\cline { 2 - 7 } & & $\begin{array}{l}\text { Action group } \\
\text { members }\end{array}$ & $228 / 240^{1}$ & $184 / 240^{1}$ & $32 / 240^{1}$ & $444 / 720$ \\
\cline { 2 - 7 } & Diaries & Facilitators & $115 / 120^{2}$ & $101 / 120^{2}$ & N.A. & $118 / 240$ \\
\cline { 2 - 7 } & Minutes & Action groups & $115 / 120$ & $101 / 120$ & N.A. & $216 / 240$ \\
\cline { 2 - 7 } & Survey & $\begin{array}{l}\text { Action group } \\
\text { members }\end{array}$ & $228 / 240^{1}$ & $184 / 240^{1}$ & $32 / 240^{1}$ & $444 / 720$ \\
\hline $\begin{array}{l}\text { Case } \\
\text { study } \\
\text { schools }\end{array}$ & FGDs & Students & $6 / 6$ & $5 / 6$ & $4 / 6$ & $15 / 18$ \\
\cline { 2 - 7 } & Staff & $6 / 6$ & $5 / 6$ & $4 / 6$ & $15 / 18$ \\
\hline
\end{tabular}

${ }^{1}$ denominator assumes 12 AGM members per intervention school

${ }^{2}$ denominator assumes 6 meetings per year for 20 schools 
Table 2: Member satisfaction with AGs

\begin{tabular}{|c|c|c|c|c|c|c|c|c|c|}
\hline \multirow{3}{*}{$\begin{array}{l}\text { Measure } \\
\text { (response } \\
\text { option } \\
\text { which } \\
\text { indicates } \\
\text { satisfactio } \\
\text { n) }\end{array}$} & \multicolumn{9}{|c|}{ Responses } \\
\hline & \multicolumn{3}{|c|}{ Year 1} & \multicolumn{3}{|l|}{ Year 2} & \multicolumn{3}{|l|}{ Year 3} \\
\hline & $\begin{array}{l}\text { Overall } \\
\% \\
\text { member } \\
s \\
\text { respond } \\
\text { ing as } \\
\text { indicate } \\
d\end{array}$ & $\begin{array}{l} \\
\text { schools } \\
\text { where } \\
>70 \% \\
\text { of } \\
\text { membe } \\
\text { rs } \\
\text { respon } \\
\text { ded as } \\
\text { indicat } \\
\text { ed }\end{array}$ & $\begin{array}{l} \\
\text { scho } \\
\text { ols } \\
\text { with } \\
\text { no } \\
\text { data }\end{array}$ & $\begin{array}{l}\text { Overall } \\
\% \\
\text { member } \\
s \\
\text { respond } \\
\text { ing as } \\
\text { indicate } \\
d\end{array}$ & $\begin{array}{l} \\
\text { schools } \\
\text { where } \\
>70 \% \\
\text { of } \\
\text { membe } \\
\text { rs } \\
\text { respon } \\
\text { ded as } \\
\text { indicat } \\
\text { ed }\end{array}$ & $\begin{array}{l}\text { N } \\
\text { scho } \\
\text { ols } \\
\text { with } \\
\text { no } \\
\text { data }\end{array}$ & $\begin{array}{l}\text { Overall } \\
\% \\
\text { member } \\
s \\
\text { respond } \\
\text { ing as } \\
\text { indicate } \\
d\end{array}$ & $\begin{array}{l} \\
\text { schools } \\
\text { where } \\
>70 \% \\
\text { of } \\
\text { membe } \\
\text { rs } \\
\text { respon } \\
\text { ded as } \\
\text { indicat } \\
\text { ed }\end{array}$ & $\begin{array}{l}\text { N } \\
\text { scho } \\
\text { ols } \\
\text { with } \\
\text { no } \\
\text { data }\end{array}$ \\
\hline $\begin{array}{l}\text { Was the } \\
\text { needs- } \\
\text { assessmen } \\
t \text { report } \\
\text { useful in } \\
\text { helping } \\
\text { the Action } \\
\text { Group } \\
\text { decide } \\
\text { what } \\
\text { actions to } \\
\text { take? } \\
\text { (somewha } \\
\text { t or very) }\end{array}$ & $91 \%$ & 17 & 1 & $88 \%$ & 14 & 3 & $76 \%$ & 2 & 17 \\
\hline $\begin{array}{l}\text { Was the } \\
\text { external } \\
\text { facilitator } \\
\text { useful in } \\
\text { ensuring } \\
\text { that all } \\
\text { Action } \\
\text { Group } \\
\text { members } \\
\text { could } \\
\text { have their } \\
\text { say? } \\
\text { (somewha } \\
\text { t or very) }\end{array}$ & $89 \%$ & 18 & 1 & $90 \%$ & 15 & 3 & N.A. & N.A. & N.A. \\
\hline $\begin{array}{l}\text { Was the } \\
\text { external } \\
\text { facilitator } \\
\text { useful in } \\
\text { helping } \\
\text { the Action } \\
\text { Group } \\
\text { decide } \\
\text { what } \\
\text { actions to } \\
\text { take? }\end{array}$ & $86 \%$ & 16 & 1 & $88 \%$ & 17 & 3 & N.A. & N.A. & $\begin{array}{l}1 \\
N . A .\end{array}$ \\
\hline
\end{tabular}




\begin{tabular}{|c|c|c|c|c|c|c|c|c|c|}
\hline $\begin{array}{l}\text { (somewha } \\
\text { t or very) }\end{array}$ & & & & & & & & & \\
\hline $\begin{array}{l}\text { Was the } \\
\text { external } \\
\text { facilitator } \\
\text { useful in } \\
\text { helping to } \\
\text { ensure } \\
\text { that } \\
\text { actions } \\
\text { were } \\
\text { actually } \\
\text { implement } \\
\text { ed? } \\
\text { (somewha } \\
\text { t or very) }\end{array}$ & $80 \%$ & 13 & 1 & $79 \%$ & 13 & 3 & N.A. & N.A. & N.A. \\
\hline $\begin{array}{l}\text { Do you } \\
\text { think the } \\
\text { LEARNI } \\
\text { NG } \\
\text { TOGETH } \\
\text { ER } \\
\text { Project } \\
\text { was a } \\
\text { good way } \\
\text { to ensure } \\
\text { students } \\
\text { contribute } \\
\text { to } \\
\text { decision- } \\
\text { making at } \\
\text { this } \\
\text { school? } \\
\text { (very or } \\
\text { quite) }\end{array}$ & $95 \%$ & 19 & 1 & $94 \%$ & 16 & 3 & $100 \%$ & 3 & 17 \\
\hline $\begin{array}{l}\text { Overall do } \\
\text { you think } \\
\text { the Action } \\
\text { Group } \\
\text { made } \\
\text { good } \\
\text { decisions } \\
\text { about } \\
\text { what } \\
\text { actions to } \\
\text { take? (\% } \\
\text { very or } \\
\text { quite) }\end{array}$ & $94 \%$ & 19 & 1 & $93 \%$ & 16 & 3 & $98 \%$ & 3 & 17 \\
\hline $\begin{array}{l}\text { Do you } \\
\text { think the } \\
\text { Action } \\
\text { Group } \\
\text { made sure }\end{array}$ & $70 \%$ & 10 & 1 & $72 \%$ & 10 & 3 & $69 \%$ & 1 & 17 \\
\hline
\end{tabular}




\begin{tabular}{|l|l|l|l|l|l|l|l|l|l|}
\hline that these & & & & & & & & & \\
actions & & & & & & & & & \\
were & & & & & & & & & \\
implement & & & & & & & & & \\
ed? $(\%$ & & & & & & & & \\
yes) & & & & & & & & & \\
\hline
\end{tabular}

*No external facilitator in Year 3. 
Table 3: Learner empowerment scale for AG members

\begin{tabular}{|c|c|c|c|c|c|c|c|c|c|}
\hline \multirow[b]{3}{*}{$\begin{array}{l}\text { Learner } \\
\text { Empower } \\
\text { ment Scale } \\
\text { item } \\
\text { (response } \\
\text { option } \\
\text { which } \\
\text { indicates } \\
\text { empowerm } \\
\text { ent) }\end{array}$} & \multicolumn{9}{|c|}{ Responses } \\
\hline & \multicolumn{3}{|c|}{ Year 1} & \multicolumn{3}{|l|}{ Year 2} & \multicolumn{3}{|l|}{ Year 3} \\
\hline & $\begin{array}{l}\text { Overall } \\
\% \\
\text { member } \\
s \\
\text { respond } \\
\text { ing as } \\
\text { indicate } \\
d\end{array}$ & $\begin{array}{l}\text { N } \\
\text { schools } \\
\text { where } \\
>70 \% \\
\text { of } \\
\text { membe } \\
\text { rs } \\
\text { respon } \\
\text { ded as } \\
\text { indicat } \\
\text { ed }\end{array}$ & $\begin{array}{l}N \\
\text { scho } \\
\text { ols } \\
\text { with } \\
\text { no } \\
\text { data }\end{array}$ & $\begin{array}{l}\text { Overall } \\
\% \\
\text { member } \\
s \\
\text { respond } \\
\text { ing as } \\
\text { indicate } \\
d\end{array}$ & $\begin{array}{l}N \\
\text { schools } \\
\text { where } \\
>70 \% \\
\text { of } \\
\text { membe } \\
\text { rs } \\
\text { respon } \\
\text { ded as } \\
\text { indicat } \\
\text { ed }\end{array}$ & $\begin{array}{l}\text { N } \\
\text { scho } \\
\text { ols } \\
\text { with } \\
\text { no } \\
\text { data }\end{array}$ & $\begin{array}{l}\text { Overall } \\
\% \\
\text { member } \\
s \\
\text { respond } \\
\text { ing yes }\end{array}$ & $\begin{array}{l}N \\
\text { schools } \\
\text { where } \\
>70 \% \\
\text { of } \\
\text { membe } \\
\text { rs } \\
\text { respon } \\
\text { ded as } \\
\text { indicat } \\
\text { ed }\end{array}$ & $\begin{array}{l}\text { N } \\
\text { scho } \\
\text { ols } \\
\text { with } \\
\text { no } \\
\text { data }\end{array}$ \\
\hline $\begin{array}{l}\text { During } \\
\text { Action } \\
\text { Group } \\
\text { meetings, I } \\
\text { felt } \\
\text { confident } \\
\text { that I could } \\
\text { do what } \\
\text { was } \\
\text { expected } \\
\text { (yes) }\end{array}$ & $90 \%$ & 18 & 1 & $91 \%$ & 14 & 3 & $98 \%$ & 3 & 17 \\
\hline $\begin{array}{l}\text { I had the } \\
\text { power to } \\
\text { make a } \\
\text { difference } \\
\text { to how } \\
\text { things were } \\
\text { done at } \\
\text { Action } \\
\text { Group } \\
\text { meetings } \\
\text { (yes) }\end{array}$ & $78 \%$ & 14 & 1 & $82 \%$ & 10 & 3 & $89 \%$ & 3 & 17 \\
\hline $\begin{array}{l}\text { The Action } \\
\text { Group's } \\
\text { work fit } \\
\text { with what I } \\
\text { believe in } \\
\text { (yes) }\end{array}$ & $88 \%$ & 17 & 1 & $92 \%$ & 17 & 3 & $89 \%$ & 3 & 17 \\
\hline $\begin{array}{l}\text { My } \\
\text { participatio } \\
\text { n was } \\
\text { important } \\
\text { to the } \\
\text { success of } \\
\text { the Action } \\
\text { Group (yes) }\end{array}$ & $83 \%$ & 16 & 1 & $81 \%$ & 14 & 3 & $86 \%$ & 3 & 17 \\
\hline $\begin{array}{l}\text { Other } \\
\text { people on } \\
\text { the Action }\end{array}$ & $92 \%$ & 19 & 1 & $79 \%$ & 15 & 3 & $89 \%$ & 2 & 17 \\
\hline
\end{tabular}




\begin{tabular}{|c|c|c|c|c|c|c|c|c|c|}
\hline $\begin{array}{l}\text { Group } \\
\text { made me } \\
\text { feel like I } \\
\text { was not } \\
\text { good } \\
\text { enough } \\
\text { (no) }\end{array}$ & & & & & & & & & \\
\hline $\begin{array}{l}\text { I actively } \\
\text { took part in } \\
\text { the tasks } \\
\text { undertaken } \\
\text { on the } \\
\text { Action } \\
\text { Group (yes) }\end{array}$ & $90 \%$ & 19 & 1 & $89 \%$ & 16 & 3 & $91 \%$ & 3 & 17 \\
\hline $\begin{array}{l}\text { I usually } \\
\text { did more } \\
\text { work than I } \\
\text { had to do } \\
\text { on the } \\
\text { Action } \\
\text { Group (yes) }\end{array}$ & $23 \%$ & 0 & 1 & $34 \%$ & 0 & 3 & $33 \%$ & 0 & 17 \\
\hline $\begin{array}{l}\text { I was } \\
\text { overwhelm } \\
\text { ed by all of } \\
\text { the work } \\
\text { required of } \\
\text { the Action } \\
\text { Group (no) }\end{array}$ & $75 \%$ & 14 & 1 & $74 \%$ & 15 & 3 & $86 \%$ & 3 & 17 \\
\hline $\begin{array}{l}\text { I worked } \\
\text { hard on the } \\
\text { Action } \\
\text { Group } \\
\text { because I } \\
\text { wanted to, } \\
\text { not because } \\
\text { I had to } \\
\text { (yes) }\end{array}$ & $83 \%$ & 17 & 1 & $83 \%$ & 14 & 3 & $84 \%$ & 2 & 17 \\
\hline $\begin{array}{l}\text { I had a } \\
\text { choice in } \\
\text { the way I } \\
\text { went about } \\
\text { doing work } \\
\text { on the } \\
\text { Action } \\
\text { Group (yes) }\end{array}$ & $86 \%$ & 17 & 1 & $90 \%$ & 17 & 3 & $86 \%$ & 3 & 17 \\
\hline $\begin{array}{l}\text { The things I } \\
\text { had to do } \\
\text { on the } \\
\text { Action } \\
\text { Group } \\
\text { meant a lot } \\
\text { to me } \\
\text { personally } \\
\text { yes) }\end{array}$ & $61 \%$ & 5 & 1 & $74 \%$ & 10 & 3 & $69 \%$ & 1 & 17 \\
\hline
\end{tabular}




\begin{tabular}{|c|c|c|c|c|c|c|c|c|c|}
\hline $\begin{array}{l}\text { I liked to } \\
\text { talk about } \\
\text { what I was } \\
\text { doing on } \\
\text { the Action } \\
\text { Group with } \\
\text { friends or } \\
\text { family } \\
\text { (yes) }\end{array}$ & $55 \%$ & 2 & 1 & $61 \%$ & 11 & 3 & $66 \%$ & 1 & 17 \\
\hline $\begin{array}{l}\text { I felt } \\
\text { nervous } \\
\text { about what } \\
\text { was } \\
\text { expected of } \\
\text { me on the } \\
\text { Action } \\
\text { Group (no) }\end{array}$ & $76 \%$ & 15 & 1 & $73 \%$ & 12 & 3 & $80 \%$ & 2 & 17 \\
\hline $\begin{array}{l}\text { I was able } \\
\text { to affect the } \\
\text { way things } \\
\text { were done } \\
\text { on the } \\
\text { Action } \\
\text { Group (yes) }\end{array}$ & $76 \%$ & 12 & 1 & $84 \%$ & 14 & 3 & $75 \%$ & 1 & 17 \\
\hline $\begin{array}{l}\text { I looked } \\
\text { forward to } \\
\text { the Action } \\
\text { Group } \\
\text { meetings } \\
\text { (yes) }\end{array}$ & $73 \%$ & 11 & 1 & $84 \%$ & 13 & 3 & $91 \%$ & 3 & 17 \\
\hline $\begin{array}{l}\text { Those } \\
\text { leading the } \\
\text { Action } \\
\text { Group } \\
\text { believed } \\
\text { that they } \\
\text { must } \\
\text { control how } \\
\text { I } \\
\text { contributed } \\
\text { to the } \\
\text { Action } \\
\text { Group (no) }\end{array}$ & $63 \%$ & 9 & 1 & $61 \%$ & 4 & 3 & $79 \%$ & 2 & 17 \\
\hline $\begin{array}{l}\text { I got } \\
\text { positive } \\
\text { responses } \\
\text { when I } \\
\text { expressed } \\
\text { my own } \\
\text { attitudes } \\
\text { and ideas } \\
\text { on the } \\
\text { Action } \\
\text { Group (yes) }\end{array}$ & $85 \%$ & 15 & 1 & $92 \%$ & 17 & 3 & $84 \%$ & 2 & 17 \\
\hline
\end{tabular}




\begin{tabular}{|c|c|c|c|c|c|c|c|c|c|}
\hline $\begin{array}{l}\text { I agree with } \\
\text { the things } \\
\text { that were } \\
\text { done on the } \\
\text { Action } \\
\text { Group (\% } \\
\text { yes) }\end{array}$ & $90 \%$ & 17 & 1 & $94 \%$ & 16 & 3 & $93 \%$ & 3 & 17 \\
\hline $\begin{array}{l}\text { I had the } \\
\text { skills } \\
\text { needed to } \\
\text { contribute } \\
\text { to the } \\
\text { Action } \\
\text { Group (yes) }\end{array}$ & $89 \%$ & 18 & 1 & $91 \%$ & 17 & 3 & $80 \%$ & 2 & 17 \\
\hline $\begin{array}{l}\text { My ability } \\
\text { to } \\
\text { contribute } \\
\text { to the } \\
\text { Action } \\
\text { Group was } \\
\text { under my } \\
\text { control } \\
\text { (yes) }\end{array}$ & $85 \%$ & 17 & 1 & $88 \%$ & 13 & 3 & $82 \%$ & 2 & 17 \\
\hline $\begin{array}{l}\text { Those } \\
\text { leading the } \\
\text { Action } \\
\text { Group felt } \\
\text { that they } \\
\text { were } \\
\text { always } \\
\text { right (no) }\end{array}$ & $71 \%$ & 11 & 1 & $69 \%$ & 9 & 3 & $72 \%$ & 2 & 17 \\
\hline $\begin{array}{l}\text { I found the } \\
\text { Action } \\
\text { Group to be } \\
\text { exciting } \\
\text { and } \\
\text { energizing } \\
\text { (yes) }\end{array}$ & $62 \%$ & 17 & 1 & $71 \%$ & 8 & 3 & $84 \%$ & 2 & 17 \\
\hline $\begin{array}{l}\text { I found the } \\
\text { Action } \\
\text { Group to be } \\
\text { interesting } \\
\text { (yes) }\end{array}$ & $87 \%$ & 17 & 1 & $90 \%$ & 15 & 3 & $86 \%$ & 1 & 17 \\
\hline $\begin{array}{l}\text { The things I } \\
\text { did on the } \\
\text { Action } \\
\text { Group were } \\
\text { valuable to } \\
\text { me yes) }\end{array}$ & $75 \%$ & 14 & 1 & $80 \%$ & 13 & 3 & $78 \%$ & 2 & 17 \\
\hline $\begin{array}{l}\text { The things I } \\
\text { learned and } \\
\text { did on the } \\
\text { Action } \\
\text { Group will }\end{array}$ & $77 \%$ & 13 & 1 & $86 \%$ & 15 & 3 & $78 \%$ & 1 & 17 \\
\hline
\end{tabular}




\begin{tabular}{|c|c|c|c|c|c|c|c|c|c|}
\hline $\begin{array}{l}\text { be helpful } \\
\text { for my } \\
\text { future yes) }\end{array}$ & & & & & & & & & \\
\hline $\begin{array}{l}\text { This Action } \\
\text { Group was } \\
\text { one of the } \\
\text { first times I } \\
\text { felt like I } \\
\text { was able to } \\
\text { contribute } \\
\text { to } \\
\text { something } \\
\text { important } \\
\text { (yes) }\end{array}$ & $43 \%$ & 0 & 1 & $45 \%$ & 3 & 3 & $27 \%$ & 0 & 17 \\
\hline $\begin{array}{l}\text { This Action } \\
\text { Group } \\
\text { taught me } \\
\text { how to } \\
\text { work well } \\
\text { together } \\
\text { with others } \\
\text { (yes) }\end{array}$ & $56 \%$ & 3 & 1 & $64 \%$ & 3 & 3 & $75 \%$ & 1 & 17 \\
\hline $\begin{array}{l}\text { This Action } \\
\text { Group } \\
\text { helped me } \\
\text { better } \\
\text { understand } \\
\text { some of the } \\
\text { problems in } \\
\text { my school } \\
\text { (yes) }\end{array}$ & $84 \%$ & 14 & 1 & $88 \%$ & 15 & 3 & $91 \%$ & 3 & 17 \\
\hline $\begin{array}{l}\text { This Action } \\
\text { Group gave } \\
\text { me the } \\
\text { chance to } \\
\text { do } \\
\text { something } \\
\text { about the } \\
\text { problems in } \\
\text { my school } \\
\text { (yes) }\end{array}$ & $82 \%$ & 15 & 1 & $92 \%$ & 16 & 3 & $88 \%$ & 2 & 17 \\
\hline $\begin{array}{l}\text { Mean } \\
\text { across all } \\
\text { items }\end{array}$ & $75 \%$ & 13 & 1 & $79 \%$ & 12 & 3 & $80 \%$ & 2 & 17 \\
\hline
\end{tabular}

